\title{
Analisis Kesalahan Siswa Kelas X SMK Bergaya Kognitif Reflektif dalam Menyelesaikan Soal Cerita Aljabar Berdasarkan Prosedur Newman
}

\author{
Ahmad Fathoni Abas ${ }^{1}$, Toto Nusantara ${ }^{1}$, Sudirman ${ }^{1}$ \\ ${ }^{1}$ Pendidikan Matematika-Universitas Negeri Malang
}

\begin{tabular}{l}
\hline \hline INFO ARTIKEL \\
\hline Riwayat Artikel: \\
Diterima: 29-01-2019 \\
Disetujui: 17-02-2019 \\
\hline
\end{tabular}

\section{Kata kunci:}

newman error analysis; reflective cognitive style; algebraic story matter; analisis kesalahan newman; gaya kognitif reflektif; soal cerita aljabar

\begin{abstract}
ABSTRAK
Abstract: This research was aimed to describe errors made by students with reflective cognitive style of class X MM SMKN Klakah Lumajang in solving word problems. Two subjects were selected to solve the word problem and then interviewed. The analysis is used the Newman Error Analysis. The results show that at the understanding level, the errors are subject skips important information; the subject does not identify the variable correctly. At the transformation level, the error is subjects unable to write equations correctly. At the proses skill level, the error is students do not continue the calculation process.

Abstrak: Penelitian ini bertujuan untuk mendeskripsikan kesalahan yang dilakukan siswa kelas X MM SMKN Klakah Kabupaten Lumajang dengan gaya kognitif reflektif dalam menyelesaikan soal cerita. Dua subjek dipilih untuk menyelesaikan soal cerita aljabar kemudian dilakukan wawancara. Analisis yang digunakan adalah Analisis Kesalahan Newman. Hasil penelitian menunjukkan pada tahap pemahaman, kesalahannya berupa; subjek melewatkan informasi penting pada soal; subjek tidak mengidentifikasi variabel dengan tepat. Tahap transformasi kesalahannya berupa subjek tidak mampu menulis persamaan yang sesuai dengan informasi pada soal. Tahap keterampilan proses kesalahannya berupa siswa tidak melanjutkan proses perhitungan sehingga tidak didapatkan selesaian secara matematis.
\end{abstract}

\author{
Alamat Korespondensi: \\ Ahmad Fathoni Abas \\ Pendidikan Matematika \\ Universitas Negeri Malang \\ Jalan Semarang 5 Malang \\ E-mail: fathoniabas83@gmail.com
}

Pemecahan masalah merupakan kegiatan penting dalam kehidupan manusia. Polya (2007) menyatakan aktivitas utama manusia selalu berkaitan dengan pemecahan masalah, bahkan sebagian besar aktivitas pikiran sadar manusia digunakan untuk menyelesaikan masalah. Adapun dalam konteks pembelajaran matematika, masalah yang berhubungan dengan kehidupan sehari-hari biasanya disajikan secara verbal atau disebut juga sebagai soal cerita (Scheiter, dkk, 2010). Soal cerita merupakan masalah paling umum yang dapat ditemui di setiap tingkatan sekolah mulai dari tingkat TK hingga Universitas (Jonassen, 2003). Soal cerita dapat menjadi sarana integrasi pembelajaran matematika yang bersifat abstrak dengan situasi nyata kehidupan siswa. Chapman (2006) berpendapat bahwa soal cerita dapat menjadi sarana penerapan pembelajaran matematika terhadap konteks kehidupan sehari-hari, dengan menggunakan soal cerita konsep-konsep abstrak matematika lebih mudah dipahami. Gerofsky (2016) berpendapat bahwa siswa dapat belajar matematika dari berbagai sudut pandang yang dikenalinya dengan mengerjakan soal cerita. Keadaan konkret pada soal cerita dapat menarik minat siswa dalam mempelajari matematika (Boaler, 2013).

Namun, terdapat kenyataan bahwa soal cerita menjadi masalah bagi sebagian besar siswa. Jupri \& Drijvers (2016) menyatakan bahwa menyelesaikan masalah soal cerita menjadi kendala utama belajar aljabar bagi siswa sekolah menengah di seluruh dunia. Di Indonesia, kesulitan siswa dalam menyelesaikan soal cerita tercermin dalam penelitian TIMSS. Secara ratarata hanya $8 \%$ siswa yang mampu menyelesaikan soal cerita aljabar, jauh dibanding rata-rata kemampuan internasional yaitu $18 \%$ (Mullis, dkk., 2008). Hal tersebut juga tercermin pada penelitian pendahuluan yang dilakukan terhadap beberapa siswa kelas X di sebuah SMK Negeri di Lumajang dalam mengerjakan soal berikut: "Lima tahun yang lalu umur Ani empat kali umur Boni, empat tahun yang akan datang dua kali umur Ani sama dengan tiga kali umur Boni ditambah 1 tahun, berapakah umur Ani sekarang?". Salah satu siswa menerjemahkan pernyataan pada soal seperti gambar 1. 


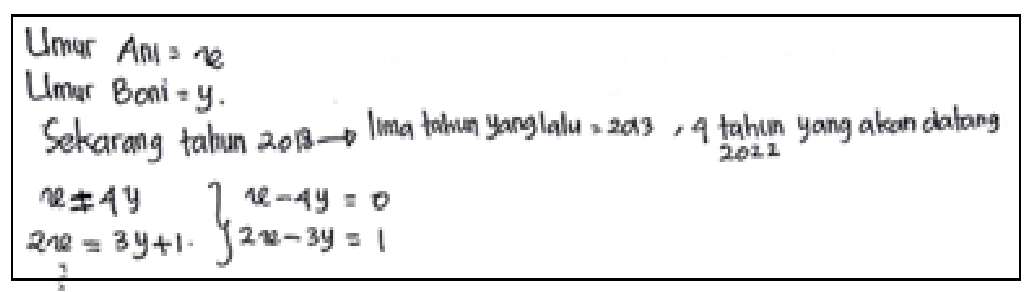

\section{Gambar 1. Jawaban Siswa pada Studi Pendahuluan}

Gambar 1 menunjukkan salah satu pekerjaan siswa. Siswa tersebut memisalkan umur Ani dan umur Boni dengan $x$ dan $y$. Kemudian ia menulis $x=4 y$ untuk menyatakan "Lima tahun yang lalu umur Ani empat kali umur Boni". Selanjutnya Ia menulis " $2 x=3 y+1$ " untuk menyatakan "empat tahun yang akan datang dua kali umur Ani sama dengan tiga kali umur Boni ditambah 1 tahun". Apabila diperhatikan, pemisalan $x$ dan $y$ pada gambar tersebut tidak tepat karena tidak menyertakan keterangan waktu dan satuan waktunya. Selain itu, dari persamaan yang disusun, $x$ mewakili dua nilai yang berbeda yaitu "umur lima tahun yang lalu" dan "umur empat tahun yang akan datang". Persamaan yang disusun tidak sesuai dengan pernyataan pada soal. Hal tersebut menyebabkan kesalahan pada penyelesaian masalah.

Kesalahan merupakan sebuah gejala dari suatu permasalahan dalam pembelajaran. Legutko (2008) menyatakan bahwa kesalahan terjadi ketika (1) seseorang memilih hal yang salah sebagai kebenaran, (2) ketika hasil tidak sesuai dengan tujuan, dan (3) ketika tindakan yang dilakukan tidak sesuai dengan prosedur. Kesalahan dapat terjadi ketika siswa menyelesaikan soal atau tugas sekolah. Adapun untuk mengetahui bagaimana kesalahan terjadi dilakukan analisis kesalahan. Menurut Brown \& Skow (2016) analisis kesalahan merupakan penilaian diagnostik yang dapat digunakan guru untuk menentukan jenis-jenis kesalahan siswa serta penyebabnya.

Adapun untuk menyelidiki kesalahan siswa dalam menyelesaikan soal cerita, digunakan Analisis Kesalahan Newman. Newman mengelompokkan kesalahan ke dalam lima tahap, yaitu (1) kesalahan membaca (reading), (2) kesalahan pemahaman (comprehansion), (3) kesalahan transformasi (transformation), (4) kesalahan keterampilan proses (process skill), dan (5) Kesalahan pengkodean (encoding). Kesalahan membaca terjadi karena siswa tidak mampu membaca dan memahami makna suatu kata atau simbol pada soal sehingga menghambatnya menyelesaikan masalah. Kesalahan pemahaman terjadi ketika siswa tidak mampu memahami kalimat yang menceritakan maksud soal secara keseluruhan. Kesalahan transformasi terjadi apabila siswa tidak mampu menggunakan metode atau strategi yang tepat untuk menyelesaikan masalah. Kesalahan ketrampilan proses terjadi apabila siswa tidak mampu melakukan pekerjaan matematis untuk menyelesaikan model matematisnya menjadi selesaian. Sedangkan kesalahan pengkodean terjadi ketika siswa tidak mampu menerjemahkan hasil perhitungan matematis menjadi solusi masalah (Fatahillah, dkk., 2017; Prakitipong \& Nakamura, 2006; White, 2005; Wijaya, dkk., 2014). Adapun untuk menyelidiki terjadinya kesalahan tersebut diperlukan analisis terhadap beberapa sumber, misalnya hasil jawaban siswa dan wawancara. Analisis kesalahan Newman dapat ditelusuri melalui wawancara diagnostik berbasis tugas (White, 2010).

Proses pemecahan masalah soal cerita dipengaruhi oleh banyak hal, salah satunya ialah gaya kognitif siswa. Rozencwajg \& Corroyer (2005) berpendapat bahwa kecepatan dan kecermatan siswa dalam menyelesaikan suatu masalah dipengaruhi oleh gaya kognitifnya. Messick (2014) juga menyatakan bahwa gaya kognitif sebagai perbedaan kebiasaan individu dalam memproses informasi seperti memahami, mengingat, berpikir, dan memecahkan masalah. Gaya kognitif berbeda dengan kemampuan kognitif. Mayer \& Massa (2003) menyatakan bahwa kemampuan berhubungan dengan bagaimana seseorang memperoleh dan memanggil informasi yang tersimpan dalam benaknya, sedangkan gaya cenderung berkaitan dengan bagaimana seseorang memproses informasi. Santrock (2007) kemudian menyatakan bahwa gaya dapat dinyatakan sebagai cara seseorang menggunakan kemampuannya.

Gaya kognitif yang berkaitan dengan konseptual tempo dibedakan menjadi dua jenis. Kagan (dalam Mann, 1973) menyatakan bahwa terdapat dua jenis gaya kognitif berdasarkan tempo, yaitu gaya reflektif dan gaya impulsif. Siswa dengan gaya reflektif cenderung mampu menyelesaikan suatu masalah dengan cukup cermat, namun diperlukan waktu cukup lama. Sebaliknya, apabila seorang siswa cenderung menyelesaikan soal dengan waktu relatif cepat, namun tidak cermat atau tidak akurat disebut memiliki gaya kognitif impulsif. Sependapat dengan Santrock (2007) yang menyatakan bahwa anak impulsif cenderung merespon dengan cepat, tetapi tidak akurat, sedangkan anak reflektif cenderung merespon dengan lambat, tetapi akurat. Sementara itu, Haghighi, dkk. (2015) menyatakan bahwa meskipun siswa reflektif menjawab lebih sedikit soal, namun terdapat lebih banyak jawaban benar daripada siswa impulsif.

Penelitian terkait pemecahan masalah oleh siswa dengan gaya kognitif reflektif dilakukan beberapa peneliti. Terkait dengan kreativitas, Warli (2013) menyatakan bahwa siswa SMP dengan gaya reflektif cenderung memiliki profil kreativitas lebih tinggi dibanding gaya impulsif dalam hal merencanakan, melaksanakan penyelesaian dan memeriksa hasil. Sementara itu, dalam hal komunikasi matematis, Margarani \& Ismail (2016) menyatakan bahwa siswa dengan gaya reflektif memiliki kemampuan komunikasi lisan secara akurat, lengkap dan lancar, tetapi komunikasi tertulisnya ditemukan tidak lengkap dan kurang akurat. Terkait dengan langkah-langkah penyelesaian masalah, Puspita \& Wijayanti (2016) menyatakan bahwa 
penyelesaian masalah secara sistematis dengan urutan yang baik dilakukan siswa reflektif sehingga prosesnya mudah dipahami orang lain dan kesalahannya cenderung lebih sedikit.

Adapun pengaruh gaya kognitif konseptual tempo dengan tingkat kesalahan yang dilakukan siswa diteliti oleh Soemantri (2018). Soemantri (2018) menegaskan bahwa semakin cepat siswa menyelesaikan masalah semakin tinggi tingkat kesalahan yang dilakukan, sedangkan semakin lama siswa menyelesaikan masalah maka kemungkinan kesalahan yang dilakukan semakin kecil. Artinya siswa reflektif cenderung lebih sedikit melakukan kesalahan dibanding siswa impulsif dalam menyelesaikan masalah. Namun begitu, Soemantri (2018) menyatakan bahwa tidak menutup kemungkinan kesalahan menyelesaikan masalah juga dilakukan oleh siswa dengan gaya kognitif reflektif. Indikasi terjadinya kesalahan tersebut tampak pada penelitian pendahuluan, seperti yang dijelaskan sebelumnya. Disamping itu, bentuk-bentuk kesalahan yang dilakukan siswa dengan gaya reflektif juga belum dijelaskan pada penelitian Soemantri (2018). Oleh karena itu, peneliti menganggap penting untuk mengetahui bentuk kesalahan yang dilakukan siswa dengan gaya kognitif reflektif dalam menyelesaikan soal cerita aljabar. Dengan mengetahui bentuk kesalahan tersebut, dapat menjadi informasi penting sebagai dasar melakukan perbaikan pembelajaran.

\section{METODE}

Jenis penelitian ini adalah penelitian kualitatif deskriptif yang berupa studi kasus. Instrumen yang digunakan pada penelitian ini yaitu lembar Matching Familiar Figure Test (MFFT), lembar tes soal cerita aljabar dan pedoman wawancara. Kelompok siswa dengan gaya kognitif reflektif diseleksi dari dua puluh lima siswa kelas X MM SMKN Klakah Kabupaten Lumajang melalui tes MFFT. Tes MFFT tersebut diadopsi dari instrumen Warli (2010). Pada MFFT, siswa diberikan suatu gambar patokan dan delapan gambar variasinya yang mirip dan hanya satu dari gambar variasi yang sama dengan gambar patokan. Tugas siswa adalah memilih satu gambar variasi yang sama dengan gambar patokan. Soal pada tes MFFT sejumlah 13 butir. Siswa digolongkan memiliki gaya kognitif reflektif apabila lambat dalam mengerjakan semua soal MFFT ( $>$ > 7,28 menit) dan menjawab salah kurang dari 7 soal ( $\mathrm{f}<7$ ). Sementara itu, siswa yang tergolong gaya kognitif impulsif adalah siswa yang cepat dalam mengerjakan semua soal MFFT ( $\mathrm{t} \leq 7,28$ menit), tetapi salahnya lebih dari atau sama dengan tujuh soal ( $\mathrm{f} \geq 7$ ). Teknik yang digunakan adalah, memanggil tiap lima siswa untuk mengerjakan MFFT kemudian dicatat waktunya. Selanjutnya hasil seluruh siswa dicocokkan dengan kunci jawaban.

Setelah didapatkan kelompok siswa dengan gaya kognitif reflektif. Kemudian, diberikan soal cerita aljabar kepada kelompok tersebut. Setelah mengerjakan soal, lalu dilakukan wawancara untuk mengkonfirmasi hasil pekerjaannya. Dalam wawancara, siswa diminta membaca lagi soal yang diberikan dengan suara yang jelas. Siswa juga diberi pertanyaan untuk menggali tahap penyelesaian soal cerita sesuai dengan prosedur Newman. Siswa yang melakukan kesalahan dalam penyelesaian masalah dan terdapat indikasi menggunakan pemodelan matematis dijadikan subjek penelitian. Data penelitian berupa hasil pekerjaan siswa dan transkrip wawancara. Soal cerita aljabar yang digunakan sebagai instrumen adalah sebagai berikut.

\begin{tabular}{|l} 
Soal \\
Seorang Ayah memiliki dua anak bernama Syifa dan Maisha di mana selisih umurnya 4 tahun. Duatahun yang lalu, \\
umur ayah adalah dua kali umur Syifa ditambah empat kali umur Maisha. Enam tahun yang akan datang, umur ayah \\
menjadi umur Syifa ditambah dua kali umur Maisha. Berapakah umur Ayah, Syifa dan Maisha sekarang?
\end{tabular}

\section{Gambar 2. Soal Tes}

Teknik analisis data dilakukan dengan cara (1) mendeskripsikan hasil pekerjaan subjek secara naratif, (2) menggambarkan struktur jawaban subjek dan (3) melakukan analisis kesalahan siswa berdasarkan analisis kesalahan Newman.

\section{HASIL}

Tes MFFT diberikan kepada 25 siswa kelas X MM SMKN Klakah dengan cara memanggil tiap lima orang untuk mengerjakan kemudian dicatat waktunya. Setelah selesai, hasil jawaban MFFT siswa dicocokkan dengan kunci jawaban. Sesuai dengan kriteria Warli (2010) siswa digolongkan dalam gaya kognitif reflektif apabila mengerjakan MFFT dengan waktu lebih dari 7.29 menit dan melakukan kesalahan paling banyak 6, sedangkan gaya kognitif impulsif apabila waktunya kurang dari 7.29 dan melakukan kesalahan lebih dari 6. Berdasarkan kriteria tersebut dari 25 siswa, terdapat 14 siswa slow-innacurate, 8 siswa reflektif dan 3 siswa impulsif.

Dari 8 siswa reflektif tersebut kemudian diberikan soal cerita aljabar dan dilakukan wawancara. Hasil pekerjaan soal menunjukkan bahwa (1) tidak terdapat satupun siswa yang menyelesaikan soal cerita dengan tepat, (2) sebagian besar siswa hanya menuliskan apa yang diketahui dan apa yang ditanyakan pada soal. Lalu, dipilih dua siswa yaitu AN dan SQ sebagai subjek penelitian. Pemilihan tersebut berdasarkan adanya kesalahan pada pekerjaannya dan adanya indikasi keduanya melakukan pemodelan matematika untuk menyelesaikan masalah. Hasil pekerjaan masing-masing subjek dalam menyelesaikan soal cerita aljabar dijabarkan pada gambar 3. 


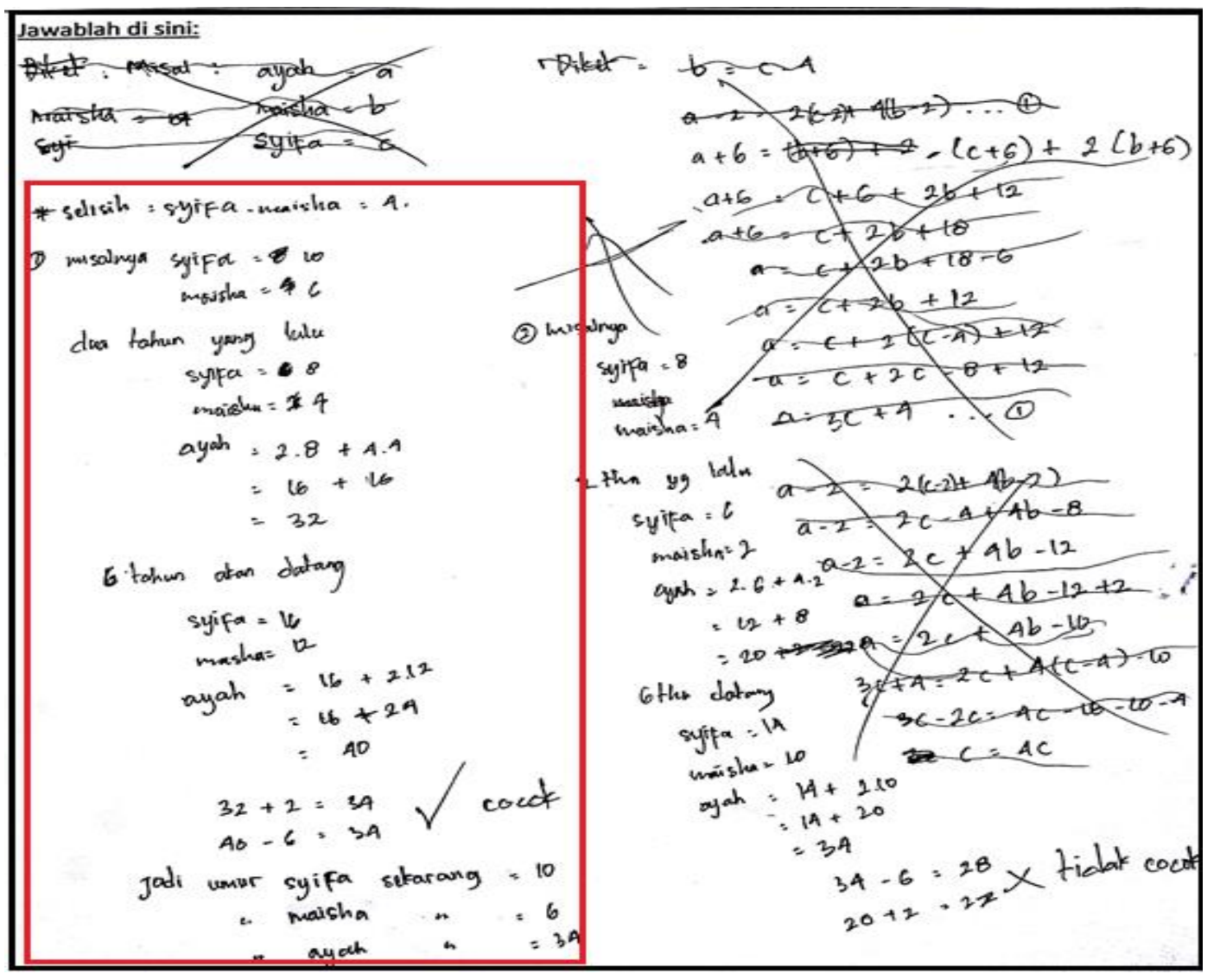

\section{Gambar 3. Hasil Pekerjaan AN}

Pada Gambar 3 tersebut tampak AN tidak menuliskan apa yang diketahui dan apa yang ditanyakan. AN tampak mencoret pekerjaannya yang bertuliskan misal ayah $=\mathrm{a}$, maisha $=\mathrm{b}$, dan syifa $=\mathrm{c}$. AN kemudian menulis \#selisih: SyifaMaisha $=4$, lalu menulis misalkan syifa $=10$ dan maisha $=6$. Selanjutnya AN menulis dua tahun yang lalu, syifa $=8$, maisha $=$ 4 , dan menghitung ayah $=2.8+4.4=16+16=32$. Lalu, AN menulis 6 tahun yang akan datang syifa $=16$, maisha $=12$, dan menghitung ayah $=16+2 * 12=16+24=40$. Kemudian AN menulis $32+2=34$ dan 40-6 = 34, cocok. Lalu menulis solusi dari soal yaitu, jadi umur syifa sekarang $=10$, umur maisha sekarang $=6$ dan umur ayah sekarang $=34$. Pada Gambar 2 tersebut juga tampak AN mencoret sebagian besar pekerjaannya yang berada di sebelah kanan pada gambar. Kemudian pada sebelah tengah hasil pekerjaan AN, tampak perhitungan tulisan misalnya Syifa $=8$, maisha $=4$, lalu dilanjutkan dengan proses yang sama dengan proses pada sebelah kiri gambar. Ketika ditanyakan kepada AN apa yang dipahami dari soal AN menjelaskan sebagai berikut.

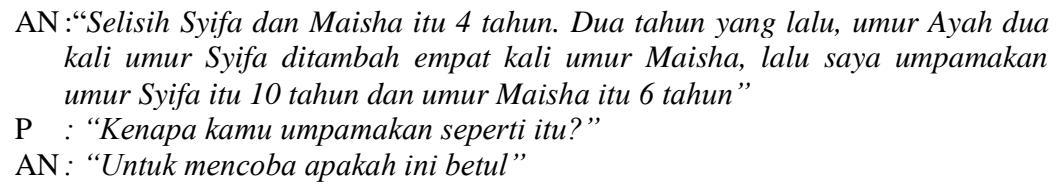

AN :"Selisih Syifa dan Maisha itu 4 tahun. Dua tahun yang lalu, umur Ayah dua kali umur Syifa ditambah empat kali umur Maisha, lalu saya umpamakan umur Syifa itu 10 tahun dan umur Maisha itu 6 tahun"

P : "Kenapa kamu umpamakan seperti itu?"

AN: "Untuk mencoba apakah ini betul"

Dialog tersebut menunjukkan bahwa AN melakukan coba-coba untuk menghitung umur Ayah. AN menggunakan keterangan "Syifa dan Maisha selisih umurnya 4 tahun" sebagai patokan awal dalam perhitungan selanjutnya. AN mengetahui bahwa yang dicari pada permasalahan tersebut adalah umur ketiganya yang memenuhi seluruh pernyataan pada soal. Peneliti selanjutnya beralih kepada jawaban AN yang dicoret. Pada bagian tersebut tampak AN melakukan proses pemodelan matematika. AN memisalkan umur Ayah = a, umur Maisha = b dan umur Syifa = c. Jawaban pada bagian yang dicoret ditampilkan pada gambar 4 . 


\begin{tabular}{|c|c|c|c|}
\hline 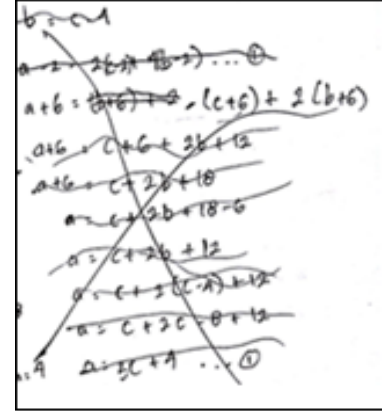 & $\begin{array}{l}b=c-4 \\
a-2=2(c-2)+4(b-2) \\
a+6=(c+6)+2(b+6) \\
a+6=c+6+2 b+12 \\
a+6=c+2 b+18 \\
a=c+2 b+18-6 \\
a=c+2 b+12 \\
a=c+2(c-4)+12 \\
a=c+2 c-8+12 \\
a=3 c+4\end{array}$ & $\begin{aligned} a-2 & =2 c-A+A b-B \\
a-2 & =2 c+a b-12 \\
a & =2 a+4 b-12+2 \\
& =2+4 b-10\end{aligned}$ & $\begin{array}{l}a-2=2(c-2)+4(b-2) \\
a-2=2 c-4+4 b-8 \\
a-2=2 c+4 b-12 \\
a=2 c+4 b-12+2 \\
a=2 c+4 b-10 \\
3 c+4=2 c+4(c-4)-10 \\
3 c-2 c=4 c-16-10-4 \\
c=4 c\end{array}$ \\
\hline
\end{tabular}

\section{Gambar 4. Hasil jawaban AN yang dicoret}

Pada Gambar 4 tersebut telihat AN berupaya mengubah pernyataan pada soal menjadi persamaan matematikanya. AN menerjemahkan "Syifa dan Maisha selisih umurnya 4 tahun" menjadi $b=c-4$. Kemudian kalimat "dua tahun yang lalu, umur ayah adalah dua kali umur Syifa ditambah empat kali umur Maisha" diterjemahkan menjadi $a-2=2(c-2)+4(b-2)$. Serta kalimat "enam tahun yang akan datang, umur ayah menjadi umur Syifa ditambah dua kali umur Maisha" diterjemahkan menjadi $a+6=(c+6)+2(b+6)$. Gambar 4 tersebut juga menunjukkan AN melakukan penyederhanaan persamaan yang disusun. Hal ini tampak pada gambar, tertulis $a=2 c+4 b-10$ dan $a=c+2 b+12$. Proses transformasi tersebut juga terkonfirmasi pada sesi wawancara. AN menjelaskan maksud penulisan persamaannya seperti pada dialog berikut.

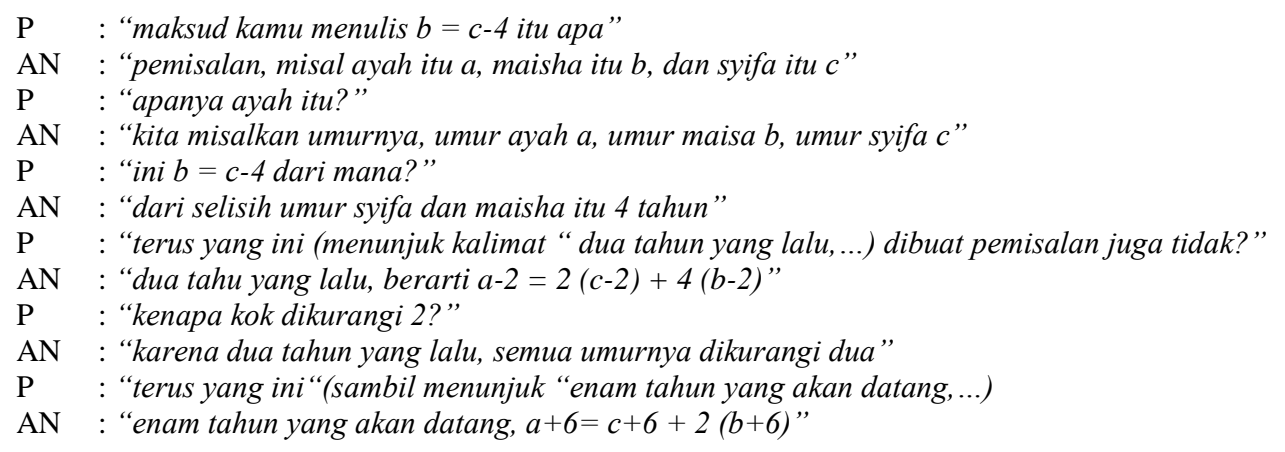

Selain proses transformasi pada gambar 4 juga terlihat proses pekerjaan matematis yang dilakukan AN untuk mendapatkan nilai $a, b$ dan $c$. AN menuliskan ketiga persamaan yang terbentuk dari pernyataan pada soal, yaitu pertama $b=$ $c-4$, kedua $a-2=2(c-2)+4(b-2)$ dan ketiga $(a+6)=(c+6)+2(b+6)$. Kemudian AN menjabarkan persamaan ketiga didapat $a=c+2 b+12$. Lalu AN mensubstitusikan nilai $b=c-4$ kedalam persamaan ketiga, didapat $a=3 c+4$. Selanjunya, AN menjabarkan persamaan kedua didapat $a=2 c+4 b-10$. Kemudian mensubstitusikan $a=3 c+4$ dan $b=$ $c-4$ pada persamaan tersebut sehingga didapat $3 c-2 c=4 c-16-10-4$. Pada proses ini seharusnya langkah terakhir didapat $c=4 c-30$, namun AN menulisnya menjadi $c=4 c$, sehingga berakibat nilai $c$ menjadi nol. Hal ini membuat AN merasa ada yang salah pada perhitungannya, lalu memutuskan menghentikan perhitungan dan mencari cara lain yaitu coba-coba untuk menyelesaikan soalnya.

Adapun apabila hasil pekerjaan AN di bandingkan dengan rubrik penilaian masalah, maka didapat beberapa kenyataan sebagai berikut yaitu (1) salah (tidak lengkap) dalam menerjemahkan "Syifa dan Maisha selisih umurnya 4 tahun" dalam kalimat matematika. Serta (2) tidak mampu mendapatkan selesaian sistem persamaan linier tiga variabel. Secara lebih lengkap struktur jawaban AN tersaji pada gambar 5. 


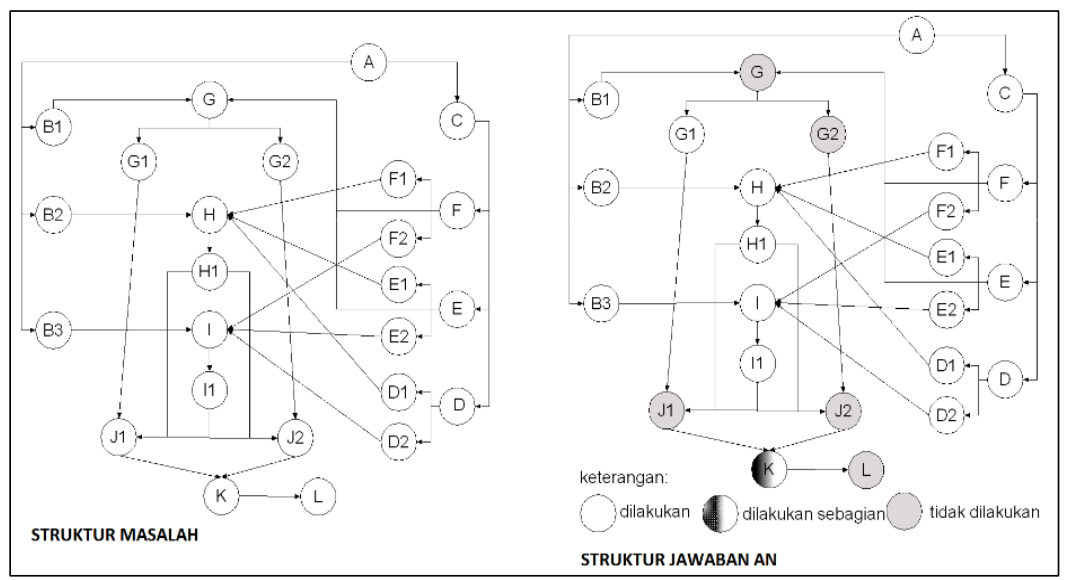

Gambar 5. Struktur Masalah dan Struktur Jawaban AN

Tabel 1. Penjelasan Kode Struktur Jawaban AN

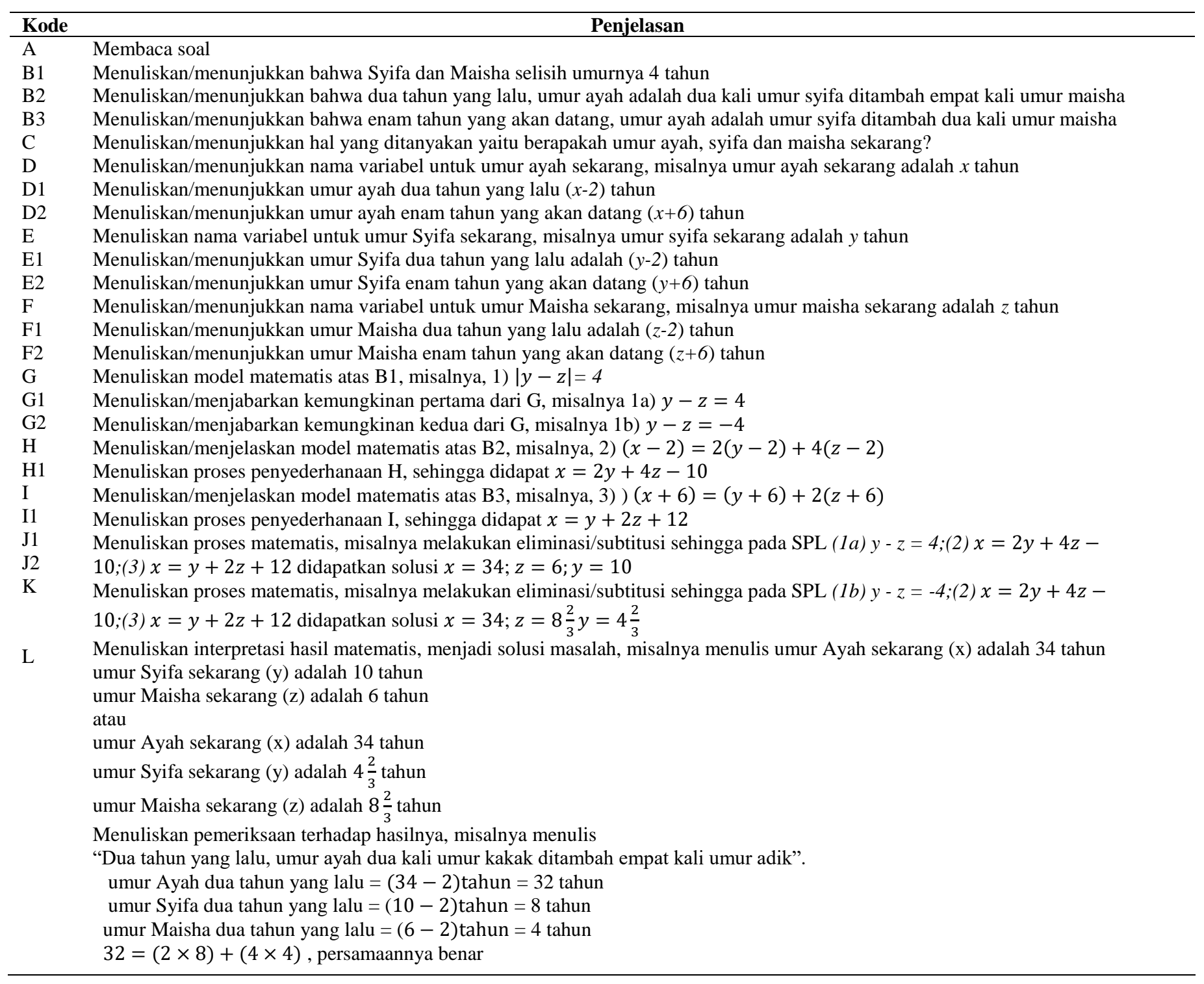


Tampak dari Gambar 5, struktur jawaban AN tidak tertulis secara runtut. Pada proses D, E dan F, AN menuliskan pendefinisian variabelnya dengan tidak tepat. AN menuliskan ayah $=\mathrm{a}$, maisha $=\mathrm{b}$, dan syifa $=\mathrm{c}$, hal ini tidak tepat karena variabel seharusnya mewakili suatu bilangan yang menyatakan umur masing-masing. Namun, pada wawancara AN dapat menjelaskan maksud penulisannya. Pada proses D1, D2, E1, E2, F1 dan F2, AN dianggap mampu melakukan prosesnya. AN mampu mengartikan frasa "dua tahun yang lalu" dengan masing masing umur dikurangi 2, serta frasa "enam tahun yang akan datang" dengan masing masing umur ditambah 6. Pada proses G, AN memandang pernyataan "umur Syifa dan Maisha berselisih 4 tahun" hanya dengan satu kemungkinan saja yaitu $\mathrm{b}=\mathrm{c}-4$. Padahal masih terdapat satu kemungkinan lagi yaitu $\mathrm{b}$ $=\mathrm{c}+4$. AN juga tampak tidak berhasil melakukan pekerjaan matematis untuk mendapatkan nilai $a, b$ dan $c$, sehingga AN tidak mampu menyelesaikan proses J1. Kemudian AN tidak melanjutkan proses penghitungannya. Pada proses K, AN mendapatkan jawaban dengan coba-coba dan mendapatkan salah satu kemungkinan solusi. Hal ini menunjukkan proses penyelesaian masalah yang dilakukan AN tidak menyeluruh. Ketidaksesuaian antara struktur masalah dengan jawaban dapat diartikan bahwa AN melakukan kesalahan dalam menyelesaikan soal. Hasil pekerjaan SQ ditampilkan pada gambar 6.

Deskripsi Proses Penyelesaian Soal Cerita oleh Subjek 2 (SQ)

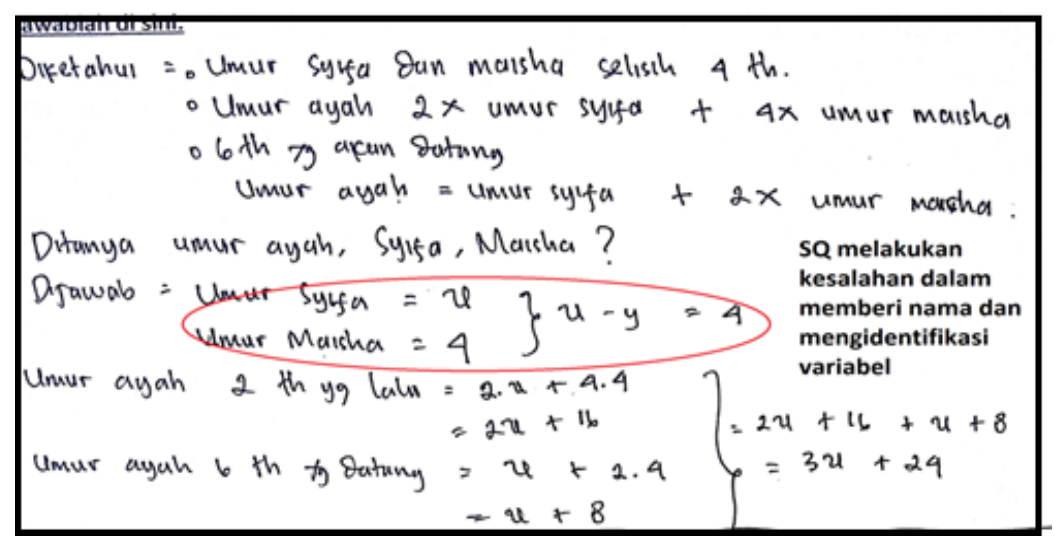

\section{Gambar 6. Hasil Pekerjaan SQ}

Pada Gambar 6 tersebut tampak SQ menuliskan apa yang diketahui dari soal. SQ menuliskan bahwa umur Syifa dan Maisha berselisih 4 tahun. SQ juga menuliskan umur ayah 2 kali umur Syifa ditambah 4 kali umur Maisha, tetapi tidak ditulis keterangan "dua tahun yang lalu”. SQ juga menulis 6 tahun yang akan datang umur ayah sama dengan umur Syifa ditambah 2 kali umur Maisha. SQ menulis "apa yang ditanyakan pada soal”. SQ menulis "ditanya umur Ayah, Syifa, Maisha?" tanpa adanya keterangan waktunya. SQ kemudian menulis "umur Syifa $=x$ ", tanpa adanya keterangan waktu dan satuan waktunya. Berikut wawancara yang dilakukan untuk mengonfirmasi apa yang dipahami SQ terhadap soal.

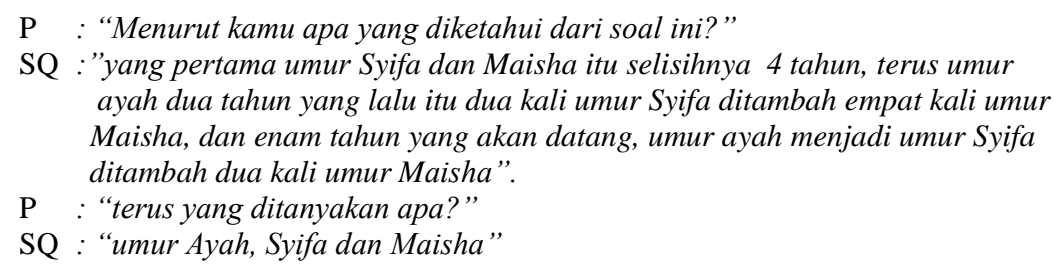

Dialog tersebut menunjukkan bahwa SQ menjelaskan informasi yang tertulis pada soal dan apa yang ditanyakan pada soal. Namun, SQ tampak tidak mempunyai cara yang tepat untuk menyelesaikan masalah. SQ melakukan coba-coba untuk mendapatkan solusi yang dicari. Wawancara untuk menyelidiki cara SQ dalam menyelesaikan masalah tersaji pada petikan dialog sebagai berikut.

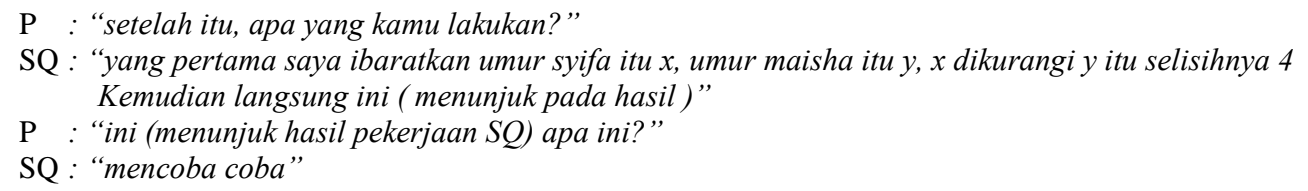


Setelah SQ merasa tidak mendapatkan jawaban yang tepat. SQ lalu mencoba lagi menggunakan pemodelan matematika. SQ membuat pemisalan umur Ayah, Syifa dan Maisha yang baru. SQ juga mencoba menerjemahkan lagi pernyataan pada soal. Gambar 7 menunjukkan hasil pemodelan yang dilakukan tersebut.

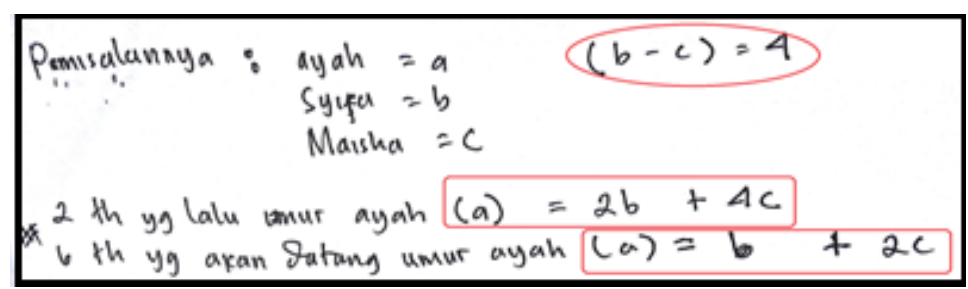

Gambar 7. Hasil Pekerjaan melakukan Pemodelan SQ

Gambar 7 tersebut menunjukkan bahwa SQ melakukan pendefinisan variable yang baru. SQ menulis ayah =a, Syifa = $\mathrm{b}$ dan Maisha $=\mathrm{c}$. Kemudian pada tulisan yang ditandai tampak SQ menerjemahkan pernyataan pada soal menjadi model matematikanya. Penjelasan SQ terhadap gambar tersebut dinyatakan sebagai berikut.

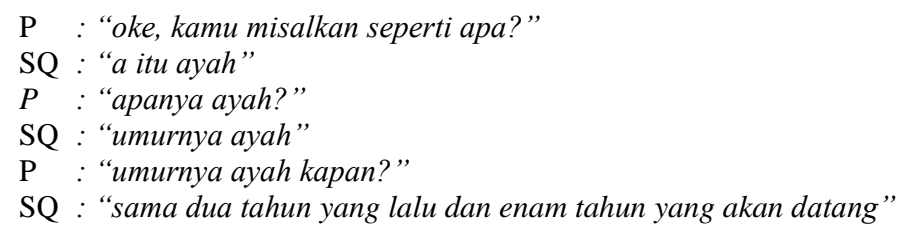

SQ membuat pemisalan $a$ sebagai Ayah. Namun, belum jelas bahwa simbol $a$ tersebut mewakili umur ayah sekarang, dua tahun yang lalu ataukah enam tahun yang akan datang. SQ menganggap nilai $a$ dapat mewakili umur nilai-nilai tersebut. SQ kemudian menyusun persamaan $a=2 b+4 c$ dan $a=b+2 c$, sebagai ekspresi pernyataan "dua tahun yang lalu, umur ayah adalah dua kali umur Syifa ditambah empat kali umur maisha" dan "enam tahun yang akan datang, umur ayah menjadi umur Syifa ditambah umur Maisha”. Artinya, SQ menuliskan pemisalan a sebagai perwakilan umur ayah dua tahun yang lalu dan umur ayah enam tahun yang akan datang.

Adapun apabila hasil pekerjaan SQ dibandingkan dengan rubrik penilaian masalah, maka didapat beberapa kenyataan yaitu (1) salah dalam menulis pendefinisian variabel, (2) tidak mampu menerjemahkan pernyataan pada soal menjadi persamaan matematikanya. Secara lebih lengkap struktur jawaban SQ tersaji pada gambar 8.

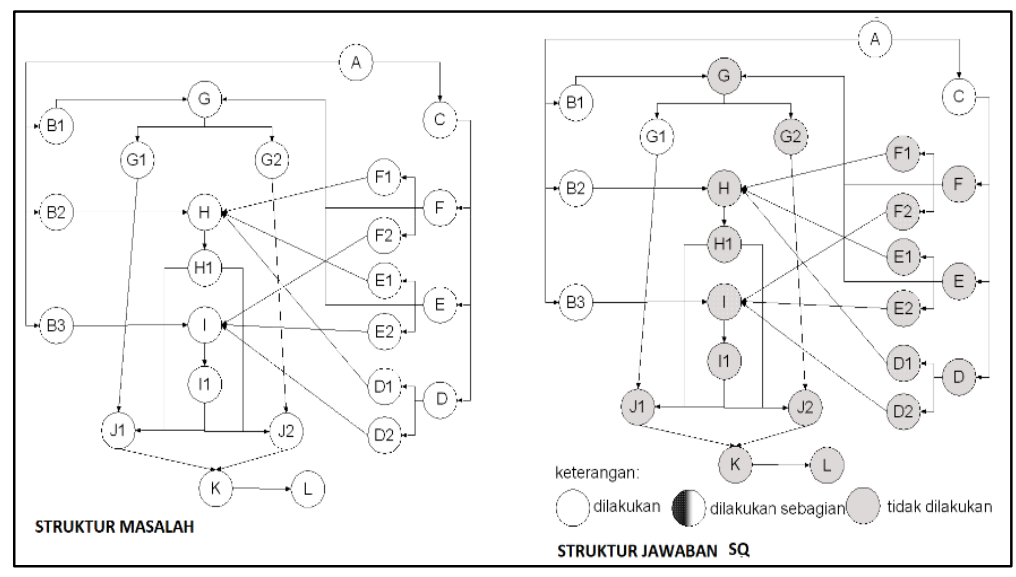

Gambar 8. Struktur Masalah dan Struktur Jawaban SQ

Adapun pada Gambar 8, tampak bahwa struktur jawaban SQ belum mengarah kepada penyelesaian masalah. Pada proses B2 SQ menulis informasi pada soal tidak lengkap, karena melewatkan keterangan "dua tahun yang lalu”. Pada proses C, SQ menuliskan hal yang ditanyakan secara tidak lengkap, karena melewatkan keterangan umur "sekarang". Akan tetapi, SQ dapat menjelaskannya ketika wawancara. Pada proses D, E dan F, SQ menuliskan pendefinisian variabelnya dengan salah. SQ menuliskan ayah $=a$, Syifa $=b$, dan Maisha $=c$, hal ini tidak tepat karena variabel seharusnya mewakili suatu bilangan. Pada proses G, SQ mengartikan pernyataan "umur Syifa dan Maisha berselisih 4 tahun" hanya dengan satu kemungkinan saja yaitu b $=c-4$. Padahal masih terdapat satu kemungkinan lagi yaitu $b=c+4$. Sedangkan pada proses $H$ dan I, SQ tidak mampu 
menerjemahkan frasa "dua tahun lalu," dan "enam tahun yang akan datang," kedalam persamaan matematikanya. Berdasarkan deskripsi jawaban dan wawancara tersebut dapat diartikan SQ tidak mampu menyelesaikan masalah. Terdapat ketidaksesuian antara struktur masalah dengan struktur jawaban SQ. Ketidaksesuaian tersebut berarti bahwa SQ melakukan kesalahan dalam menyelesaikan soal.

\section{PEMBAHASAN}

Tujuan penulisan artikel ini adalah untuk mendeskripsikan kesalahan yang dilakukan oleh siswa dengan gaya kognitif reflektif berdasarkan analisis kesalahan Newman. Newman (White, 2005) mengelompokkan proses penyelesaian masalah soal cerita ke dalam lima tahap, yaitu (1) tahap membaca (reading), (2) tahap pemahaman (comprehension), (3) tahap transformasi (transformation), (4) tahap keterampilan proses (process skill), dan (5) tahap pengkodean (encoding). Pada tahap membaca, tidak ditemukan kesalahan pada kedua subjek. White (2005) menyatakan kesalahan membaca terjadi apabila siswa tidak mampu membaca sebuah kata yang menjadi kunci dalam pemecahan masalah. Kedua subjek dapat membaca tiap kata pada soal. Salah satu contohnya, keduanya mengetahui arti kata "selisih" pada soal. Keduanya menyatakan bahwa selisih adalah umur yang lebih tua dikurangi umur yang muda.

Pada tahap pemahaman, berdasarkan hasil pekerjaan, tampak kedua subjek tidak menuliskan apa yang diketahui dan ditanyakan. Menurut Santoso, dkk. (2017) siswa dikatakan melakukan kesalahan pemahaman apabila tidak menuliskan informasi tentang apa yang diketahui dan ditanyakan dengan tepat. Namun, pada wawancara keduanya mampu menunjukkan hal-hal yang diketahui dan ditanyakan pada soal. Artinya, jawaban tertulis siswa reflektif dalam menyatakan apa yang diketahui dan ditanyakan tidak cermat dan tidak akurat. Akan tetapi, jawaban lisan menunjukkan siswa reflektif memahami hal tersebut. Hal ini juga ditemukan pada penelitian Margarani \& Ismail (2016) yang menyatakan bahwa siswa dengan gaya reflektif memiliki kemampuan komunikasi lisan secara akurat, lengkap dan lancar, tetapi komunikasi tertulisnya ditemukan tidak lengkap dan kurang akurat.

Adapun terkait tahap comprehension yang dilakukan kedua subjek. Terdapat perbedaan tingkat pemahaman kedua subjek terhadap soal. Subjek 1(AN) cenderung lebih memahami masalah dibanding SQ. Hal ini tampak dari langkah AN merencanakan penyelesaian masalah. AN mencoba menyelesaikan masalah dengan pemodelan matematika. Meskipun tidak mendapatkan selesaian, akan tetapi AN mampu menyusun persamaan linier sebagai model atas pernyataan pada soal. AN juga melakukan cara coba-coba dengan memanfaatkan informasi pada soal untuk menemukan solusi soal. Sedangkan SQ tampak tidak memiliki rencana untuk menyelesaikan soal. SQ melakukan coba-coba untuk menyelesaikan masalah, tetapi tidak tepat dalam menggunakan informasi pada soal.

Tahap pemahaman juga terkait dengan kemampuan siswa mengenali dan menggunakan informasi yang relevan untuk memecahkan masalah. Wijaya, dkk. (2014) menyatakan bahwa kesalahan pemahaman muncul ketika siswa tidak mampu mengenali informasi penting yang memengaruhi masalah. Salah satu informasi penting yang memengaruhi penyelesaian masalah pada soal yang diberikan adalah frasa "dua tahun yang lalu" dan frasa "enam tahun yang akan datang". Apabila dimisalkan umur Ayah sekarang adalah $a$ tahun, dengan adanya frasa "dua tahun yang lalu" umur Ayah secara tidak langsung berubah menjadi (a-2) tahun. AN mampu menerjemahkan hal tersebut ke dalam persamaan yang disusunnya, sedangkan SQ tidak mampu mengartikan frasa tersebut ke dalam persamaan yang disusunnya. SQ menyatakan bahwa umur ayah "sekarang" dan "dua tahun yang lalu" memiliki label yang sama. SQ memisalkan $a$ adalah label dari "ayah". SQ menggunakan simbol $a$ tersebut untuk menyatakan umur ayah "sekarang" "dua tahun yang lalu" dan "enam tahun yang akan datang". Hal ini menyebabkan $a$ mewakili beberapa nilai. Kesalahan ini disebut oleh Soneira, dkk. (2017) sebagai referensi ganda pada variabel (multiple referents of the unknown), yaitu kesalahan pendefinisian variabel (unknown) sehingga memiliki beberapa referensi nilai.

Adapun penyebab terjadinya kesalahan referensi ganda pada variabel dapat diamati dari pemahaman konsep variabel. Kesalahan multiple referents of the unknown terjadi karena pemahaman siswa terhadap konsep variabel (unknown) sebagai sebuah nilai/bilangan masih lemah. Filloy, dkk. (2004) berpendapat bahwa variabel merupakan suatu nilai yang menyatakan kuantitas tertentu misalnya, panjang, harga, umur dan lain-lain. Kesalahan penggunaan variabel didasari karena siswa menganggap variabel sebagai label/simbol yang mewakili suatu benda tertentu. Pada masalah tersebut SQ gagal membuat representasi terkait umur Ayah, Syifa dan Maisha. SQ menganggap $a, b$ dan $c$ bukan sebagai nilai, melainkan sebagai label, yaitu $a$ sebagai "Ayah", $b$ sebagai "Syifa" dan c sebagai "Maisha". Kesalahan konsepsi variabel tersebut membuat penyusunan persamaan linier juga salah.

Pada tahap transformasi, kesalahan ditemukan pada kedua subjek. Menurut (White, 2005) kesalahan transformasi terjadi ketika siswa memahami masalah pada soal cerita namun tidak mampu mengidentifikasi metode atau strategi untuk menyelesaikannya. Secara teknis, Prakitipong \& Nakamura (2006) menyatakan bahwa kesalahan transformasi terjadi ketika siswa tidak mampu menerjemahkan pernyataan verbal pada soal cerita menjadi interpretasi matematisnya. Kesalahan ini tampak ketika kedua subjek menerjemahkah pernyataan "Syifa dan Maisha selisih umurnya 4 tahun" dengan $b-c=4$, dimana $\mathrm{b}$ menyatakan umur Syifa dan c menyatakan umur Maisha. Padahal pada soal tidak tertulis keterangan bahwa Syifa lebih tua dibanding Maisha ataupun sebaliknya. Artinya pernyataan tersebut seharusnya diterjemahkan menjadi $|b-c|=4$, dimana terdapat dua kemungkinan. Apabila Syifa lebih tua, persamaannya $b-c=4$, namun apabila Maisha lebih tua persamaannya $b-c=-4$. 
Kesalahan transformasi yang lain juga ditemukan pada SQ. Ia menerjemahkan pernyataan "dua tahun yang lalu, umur Ayah adalah dua kali umur Syifa ditambah empat kali umur Maisha" dengan $a=2 b+4 c$ dan pernyataan "enam tahun yang akan datang, umur Ayah menjadi umur Syifa ditambah dua kali umur Maisha" dengan $a=b+2 c$. Kesalahan ini terjadi karena pendefinisian variabel pada tahap pemahaman yang tidak tepat. SQ memandang $a$ sebagai simbol "ayah", bukan mewakili suatu bilangan sebagai umur "ayah". Sehingga simbol $a$ digunakan pada dua persamaan meskipun mewakili nilai yang berbeda. Hal ini menunjukkan bahwa kesalahan pada tahap pemahaman menyebabkan kesalahan pada tahap transformasi. Hal ini sejalan dengan penelitian Raduan, (2010) bahwa pada tahap transformasi seorang siswa harus memahami masalah dengan benar dan merencanakan dengan saksama. Selama merencanakan penyelesaian soal, siswa akan meneliti, merekam dan mengambil semua data yang diperlukan untuk memahami masalah. Dalam fase ini, siswa akan menemukan hubungan antara informasi dan persamaan yang akan disusun. Dalam perencanaan, siswa akan menggunakan semua pengalamannya untuk menyelesaikan masalah. Siswa yang gagal memahami informasi soal akan kesulitan merancang strategi penyelesaian soal.

Pada tahap keterampilan proses, kesalahan ditemukan pada subjek 1(AN). AN menyusun sistem persamaan linier tiga variabel dari pernyataan pada soal. AN melakukan substitusi persamaan satu ke persamaan dua. Kemudian hasilnya disubstitusikan ke persamaan tiga. Pada prosesnya terdapat kesalahan perhitungan sehingga AN gagal mendapatkan selesaiannya. Kesalahan tersebut cenderung karena kecerobohan AN dalam melakukan penjumlahan bentuk aljabar. Menurut White (2005) kesalahan keterampilan proses terjadi ketika siswa sudah mampu mengidentifikasi metode/strategi penyelesaian, namun tidak mengetahui prosedur secara rinci untuk mendapatkan solusi. Sementara itu, Prakitipong \& Nakamura (2006) menjelaskan tahap keterampilan proses dapat terjadi apabila siswa melakukan proses perhitungan matematis secara benar sesuai tahapan penyelesaian masalah. Kesalahan terjadi apabila siswa tidak dapat menentukan tahapan-tahapan serta tidak mampu melakukan operasi hitung secara sistematis untuk mendapatkan jawaban akhir yang diinginkan. Pada kasus AN, ia melakukan kesalahan keterampilan proses yaitu tidak melanjutkan proses perhitungan dengan menggunakan pemodelan matematis sehingga prosesnya berhenti.

Adapun tahap pengkodean, kesalahan tidak dapat diamati dari kedua subjek. Hal ini karena kedua subjek belum dapat melakukan tahapan keterampilan proses. Prakitipong \& Nakamura (2006) menyatakan bahwa tahapan pengkodean atau penulisan jawaban dapat terjadi apabila siswa menuliskan jawaban secara lengkap dan tepat. Kesalahan pengkodean terjadi apabila siswa tidak menuliskan jawaban secara lengkap sesuai dengan permintaan soal. Berkaitan dengan beberapa kesalahan yang sering diakukan siswa ketika menyelesaikan soal cerita. Didapat fakta bahwa kedua subjek melakukan kesalahan pada tahap pemahaman dan transformasi. Temuan Wijaya, dkk. (2014) juga menegaskan bahwa kesalahan pemahaman dan kesalahan transformasi lebih sering ditemukan dibanding kesalahan pada proses yang lain. Kesalahan semacam ini merupakan kesalahan tahap awal pada proses pemodelan matematika yaitu proses memahami soal cerita dan mengubahnya menjadi masalah matematika.

Adapun terkait dengan gaya kognitif reflektif. Penulis menemukan bahwa meskipun keduanya melakukan beberapa kesalahan dalam proses penyelesaian masalah, namun keduanya masih mencoba menyelesaikan masalah dengan cara lain. Keduanya juga mampu menilai pekerjaan mereka sendiri. Salah satu contohnya, AN menghentikan perhitungan setelah mengetahui hasilnya $c=0$, kemudian melanjutkan dengan cara coba-coba, sedangkan SQ mencoba melakukan pemodelan matematika setelah penghitungan dengan melakukan coba-coba tidak mendapatkan solusi tepat. Berkaitan dengan hal tersebut Santrock (2007) menjelaskan bahwa siswa reflektif cenderung lebih baik dalam hal (a) mengingat informasi yang terstruktur, (b) membaca dengan memahami dan menginterpretasikan teks, dan (c) memecahkan masalah dan membuat keputusan. Pada penelitian ini beberapa poin yang disampaikan Santrock (2007) belum dapat diamati. Hal ini dikarenakan kedua subjek belum terbiasa mengerjakan soal yang diberikan berdasarkan langkah-langkah pemodelan matematika.

\section{SIMPULAN}

Berdasarkan pembahasan hasil penelitian dapat disimpulkan bahwa kesalahan-kesalahan yang dilakukan siswa dengan gaya kognitif reflektif dalam menyelesaikan soal cerita sebagai berikut. Pada tahap pemahaman, kesalahan yang dilakukan berupa (a) subjek melewatkan informasi penting yang memengaruhi penyelesaian masalah dan (b) subjek tidak mampu mengidentifikasi variabel (unknown) dengan tepat. Pada tahap transformasi, kesalahan yang dilakukan berupa subjek tidak mampu menulis persamaan yang sesuai dengan informasi pada soal. Pada tahap keterampilan proses kesalahan yang dilakukan berupa siswa tidak melanjutkan proses perhitungan sehingga tidak didapatkan selesaian secara matematis.

Penelitian ini hanya terbatas pada kelas X MM SMKN Klakah. Oleh karena itu, tidak dapat diambil generalisasi kesimpulan. Agar dapat diambil kesimpulan yang lebih mendalam, perlu dilakukan penelitian secara kuantitatif dimana melibatkan siswa dengan gaya reflektif yang lebih banyak. Selain itu, langkah-langkah perbaikan pembelajaran perlu dilakukan untuk mengatasi kesalahan siswa dalam menyelesaikan soal cerita. Langkah-langkah perbaikan tersebut perlu memanfaatkan gaya kognitif reflektif dimana memiliki karakteristik lambat, namun cenderung cermat. 


\section{DAFTAR RUJUKAN}

Boaler, J. (2013). The Role of Contexts in the Mathematics Classroom: Do They Make Mathematics More "Real"? For the Learning of Mathematics, 13(2), 12-17.

Brown, J., \& Skow, K. (2016). Identifying Error Patterns. In Mathematics: Identifying and Addressing Student Errors (hal. 1620). http://doi.org/10.1002/ejoc.201200111

Chapman, O. (2006). Classroom Practices for Context of Mathematics Word Problems. Educational Studies in Mathematics, 62(2), 211-230. http://doi.org/10.1007/s10649-006-7834-1

Fatahillah, A., Wati, Y. F., \& Susanto. (2017). Analisis Kesalahan Siswa dalam Menyelesaikan Soal Cerita Matematika Berdasarkan Tahapan Newman Beserta Bentuk Scaffolding yang Diberikan. Kadikma, 8(1), 40-51.

Filloy, E., Rojano, T., \& Solares, A. (2004). Arithmetic/Algebraic Problem-Solving and The Representation of Two Unknown Quantities. In Proceedings of the 28th Conference of the International Group for the Psychology of Mathematics Education (Vol. 2, hal. 391-398).

Gerofsky, S. (2016). A Linguistic and Narrative View of Word Problems in Mathematics Education. For the Learning of Mathematic, 16(2), 36-45.

Haghighi, M., Ghanavati, M., \& Rahimi, A. (2015). The Role of Gender Differences in the Cognitive Style of ImpulsivityReflectivity and EFL Success. Procedia - Social and Behavioral Sciences, 192, 467-474. http://doi.org/10.1016/j.sbspro.2015.06.072

Jonassen, D. H. (2003). Designing Research-Based Instruction for Story Problems. Educational Psychology Review, 15(3), 267-296. http://doi.org/10.1023/A:1024648217919

Jupri, A., \& Drijvers, P. (2016). Student Difficulties in Mathematizing Word Problems in Algebra. Eurasia Journal of Mathematics, Science \& Technology Education, 12(9), 2481-2502. http://doi.org/10.12973/eurasia.2016.1299a

Legutko, M. (2008). An Analysis of Students'Mathematical Errors in the Teaching-Research Process. Handbook for Mathematics Teaching: Teacher Experiment. A Tool for Research, 141-152.

Mann, L. (1973). Differences between Reflective and Impulsive Children in Tempo and Quality of Decision Making. Child Development, 44(2), 274-279. http://doi.org/10.2307/1128047

Margarani, R., \& Ismail. (2016). Profil Kemampuan Komunikasi Matematika Siswa dalam Memecahkan Masalah Matematika Ditinjau dari Gaya Kognitif Reflektif-Impulsif. Jurnal Ilmiah Pendidikan Matematika, 3(5), 500-508.

Mayer, R. E., \& Massa, L. J. (2003). Three Facets of Visual and Verbal Learners: Cognitive Ability, Cognitive Style, and Learning Preference. Journal of Educational Psychology, 95(4), 833-846. http://doi.org/10.1037/0022-0663.95.4.833

Messick, S. (2014). The Nature of Cognitive Styles: Problems and Promise in Educational Practice. Educational Psychologist, 19(2), 59-74. http://doi.org/10.1080/00461528409529283

Mullis, I. V., Martin, M. O., \& Foy, P. (2008). TIMMSS 2007 International Mathematics Report: Findings from IEA's Trends in International Mathematics and Science Study at the Fourth and Eighth Grades. Diambil dari http://isc.bc.edu/timss2003i/mathD.html

Polya, G. (2007). How To Solve It: A New Aspect of Mathematics Method. Garden City,NY: Princeton University Press.

Prakitipong, N., \& Nakamura, S. (2006). Analysis of Mathematics Performance of Grade Five Students in Thailand using Newman Procedure. Journal of International Cooperation in Education, 9(1), 111-122. http://doi.org/10.1016/j.vacuum.2008.04.036

Puspita, A. Y. A., \& Wijayanti, P. (2016). Profil Pemecahan Masalah Matematika Siswa Pada Materi Segiempat Ditinjau dari Gaya Kognitif Reflektif dan Impulsif. Jurnal Ilmiah Pendidikan Matematika, 3(5), 18-26.

Raduan, I. H. (2010). Error Analysis and the Corresponding Cognitive Activities Committed by Year Five Primary Students in Solving Mathematical Word Problems. Procedia - Social and Behavioral Sciences, 2(2), 3836-3838. http://doi.org/10.1016/j.sbspro.2010.03.600

Rozencwajg, P., \& Corroyer, D. (2005). Cognitive Processes in the Reflective-Impulsive Cognitive Style. Journal of Genetic Psychology, 166(4), 451-463. http://doi.org/10.3200/GNTP.166.4.451-466

Santoso, D. A., Farid, A., \& Ulum, B. (2017). Error Analysis of Students Working about Word Problem of Linear Program with NEA Procedure. Journal of Physics: Conference Series, 855(1). http://doi.org/10.1088/1742-6596/855/1/012043

Scheiter, K., Gerjets, P., \& Schuh, J. (2010). The Acquisition of Problem-Solving Skills in Mathematics: How Animations can Aid Understanding of Structural Problem Features and Solution Procedures. Instructional Science, 38(5), $487-502$. http://doi.org/10.1007/s11251-009-9114-9

Soemantri, S. (2018). Pengaruh Gaya Kognitif Konseptual Tempo terhadap Tingkat Kesalahan Siswa. Didaktis: Jurnal Pendidikan dan Ilmu Pengetahuan, 18(1), 74-85.

Soneira, C., González-calero, J. A., \& Arnau, D. (2017). Indexical Expressions in Word Problems and Their Influence on Multiple Referents of the Unknown. International Journal of Science and Mathematics Education, 1-21. http://doi.org/10.1007/s10763-017-9824-4

Warli. (2013). Kreativitas Siswa SMP yang Bergaya Kognitif Reflektif atau Impulsif dalam Memecahkan Masalah Geometri. Jurnal Pendidikan dan Pembelajaran, 20(2), 190-201. 
224 Jurnal Pendidikan, Vol. 4, No. 2, Bln Februari, Thn 2019, Hal 213-224

White, A. L. (2005). Active Mathematics in Classrooms: Finding out why children make mistakes - and then doing something to help them. Square One, 15(4), 15-19.

White, A. L. (2010). Numeracy, Literacy and Newman's Error Analysis. Journal of Science and Mathematics Education in Southeast Asia, 33(2), 129-148.

Wijaya, A., Heuvel-panhuizen, M. Van Den, Doorman, M., \& Robitzch, A. (2014). Difficulties in Solving Context-based PISA mathematics tasks : An analysis of students' errors. The Mathematics Enthusiast, 11(3), 555-584. http://doi.org/10.1139/t02-118 